\title{
1. Introduction: scanning literature on institutions, organizations and innovation
}

\section{Steven Casper and Frans van Waarden}

\section{DIFFERENCES IN NATIONAL INNOVATIVE PERFORMANCE}

Countries differ in their innovative performance. Porter (1990) has shown that commercial innovative activity is not spread evenly across nations. But countries differ also in other indicators of innovative output: number of patents registered, new products and processes developed, new firms founded in new promising sectors, successful marketing and commercialization, and their trade balance in high-tech products.

Countries differ not only in how much they innovate, but also in what they innovate in. Each country seems to have its own specific innovation profile. Figures 1.1 and 1.2 present patent data on industry specialization for the years 1983-84 and 1993-94 from the European Patent Office (EPO) for Germany and the United States. These data reveal that Germany has tended to specialize in well-established but relatively complex products, involving intricate production processes and after-sales services, with close, long-term customer links. These include most engineering and process-oriented industries (machine tools, engineering elements, engines, materials processing, and so forth). Germany does not patent extensively in most of the newer, more radically innovative technologies, such as biotechnology, telecommunications or information technology. Firms located in the United States, by contrast, have developed an almost inversely related patenting profile, specializing primarily in a range of high-tech industries characterized by radical innovation (biotechnology, information technology, telecommunications) but not in the spectrum of process and engineering industries dominated by German firms.

Most Northern European economies, with the exception of the UK and France, have patent profiles that resemble Germany's. For example, while we do not have systematic data on Dutch patent specialization, figures from the Dutch Economics Ministry competitiveness reports (Dutch Ministry of 


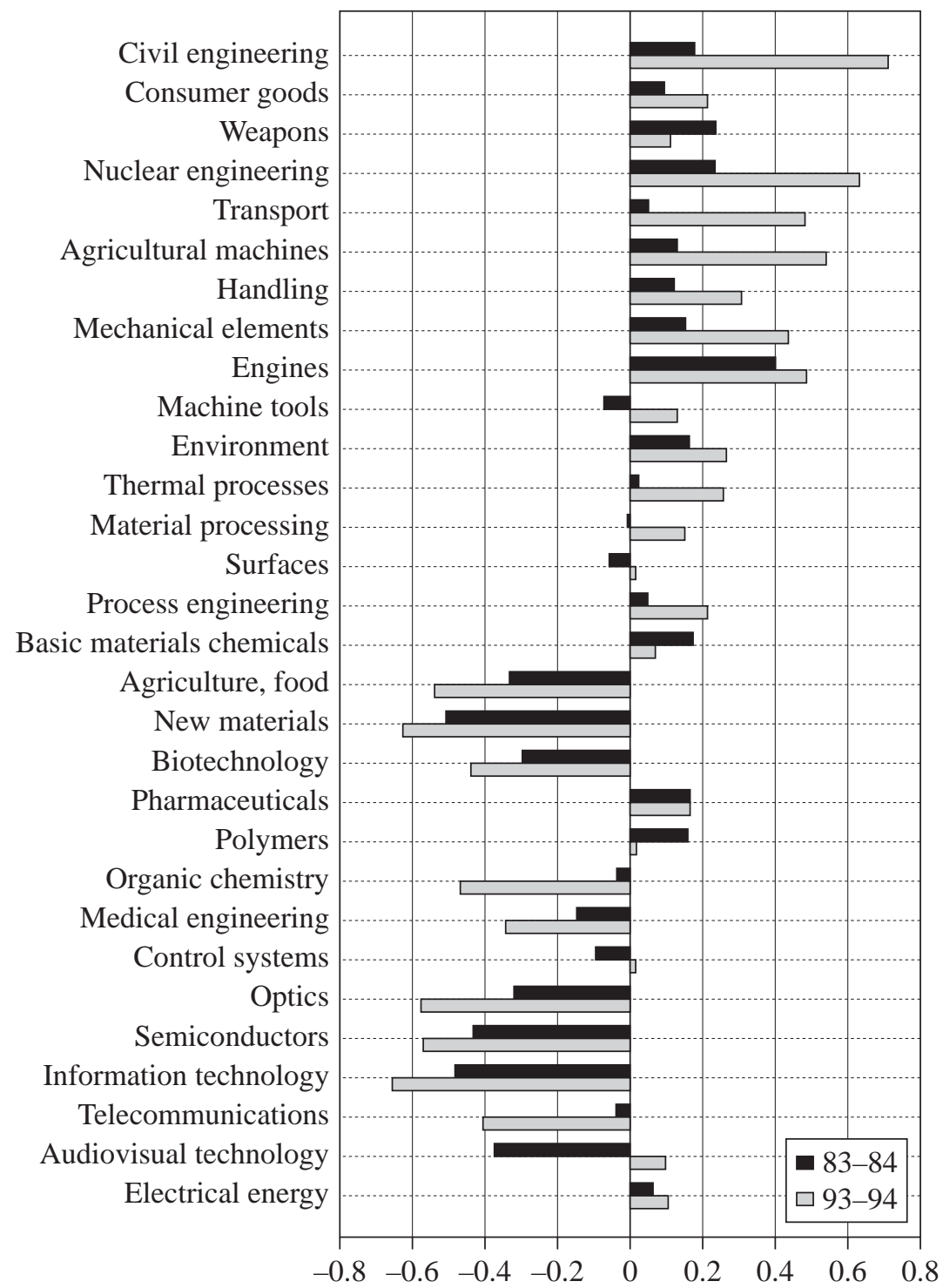

Source: European Patent Office

Figure 1.1 German patent specialization 1983-84 and 1993-94 


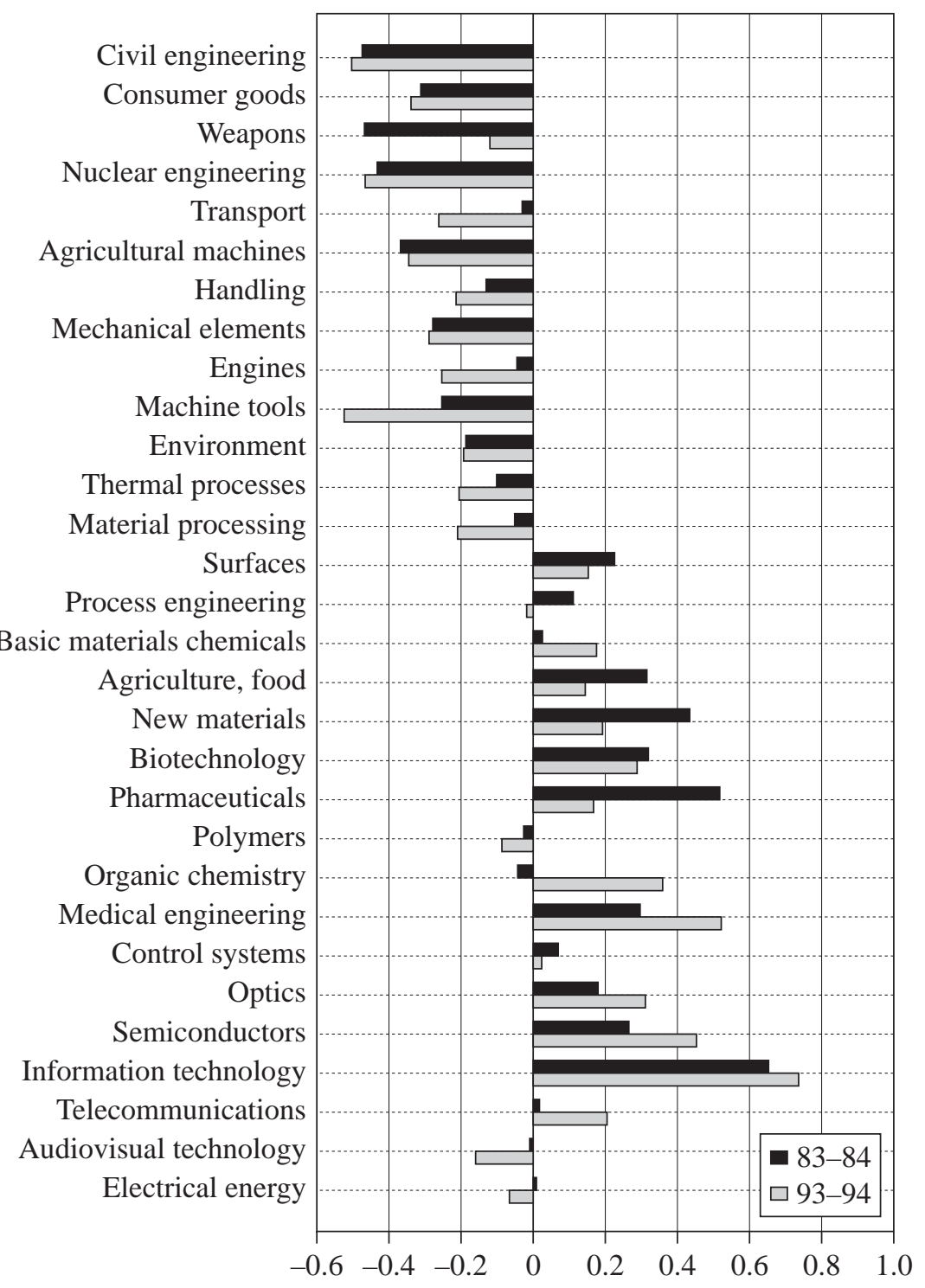

Source: European Patent Office

Figure 1.2 US patent specialization 1983-84 and 1993-94 
Economic Affairs 1995 and 1997) indicate that patterns of industry specialization also exist in the Netherlands. Citation index data indicate that, compared to the OECD average, Dutch research clusters in broadly similar areas to those seen in Germany: materials, civil engineering, chemical technologies, agrosciences, industrial engineering and chemicals. Data on Research and Development (R\&D) intensity reveal that investment in high-technology industries such as computers, information technology and electronics is low in the Netherlands. Sweden and Denmark share broadly similar profiles. The UK, Canada and Australia, on the other hand, appear to share patterns of sectoral specialization resembling those in the United States (Hall and Soskice 2001). France, on the other hand, appears to have a relatively distinct profile - performing relatively poorly in process-oriented industries, but well in industries characterized by mass production (automobiles) and industries in which large-scale systems integration, often organized by the state, is important (nuclear power, high speed trains) (Amable and Hancke 2001).

Such differences in innovation output have traditionally been explained in the economics of innovation by differences in input: amount of investment in Research and Development, capital investment in general, supply of qualified labour, and so on. In so far as institutions were included in the analysis, they were mainly perceived as impediments and constraints: to flexibility, change, adaptation, innovation. The policy prescriptions were predictable, simple and repetitive: the government should stimulate firms to invest more in $R \& D$, in part by doing so itself, or by subsidizing private investment; and regulatory straightjackets should be deregulated. A low score on expenditures on $R \& D$ or on university education in an innovation benchmark study is often an occasion to plead for more of such expenditures.

However, input factors alone cannot explain national differences in innovative performance. While R\&D related public expenditures have varied over time across various countries, the sectoral specializations of countries appear to have been quite consistent over time. The patent specialization patterns in Figures 1.1 and 1.2 have been quite stable. Even ongoing economic internationalization and liberalization have not affected these differences. On the contrary, the data in the figures indicate that the degree of specialization has consistently increased between 1983-84 and 1993-94. In virtually every category where German or US firms held a relative patenting specialization during 1988-89, it had increased in 1993-94. Country specializations are even more stable than indicated by these data, which compare only a decade. Germany has continued to be enormously innovative in industries in which it was already competitive before World War II and even in the 19th century: paper, printing, materials, machinery, electro-technical products, motor vehicles, chemicals and textiles. However, it has been much less successful in newly emerging complex, knowledge-intensive industries such as 
biotechnology, electronics and aircraft manufacturing. The Americans, in contrast, have in more recent years made radical innovations in these and other industries which have short product life cycles and are based on rapidly changing and complex technologies. In doing so, they have also succeeded in creating totally new industries with significant economic impact.

A second argument why inputs cannot be the explanation is that there are even important cases of an inverse relation between $R \& D$ expenditures and successful commercial innovation and economic performance. The European White Paper on Growth, Competitiveness, Employment (European Commission 1994) and the Green Paper on Innovation (European Commission 1995) identified what has become known as the European paradox: notwithstanding its relatively high expenditures on $R \& D$, the European economy is characterized by an 'insufficient capacity to innovate, to launch new products and services, to market them rapidly and, finally, to react rapidly to changes in demand' (European Commission 1995: 7), or a 'comparatively limited capacity to convert scientific breakthroughs and technological achievements into industrial and commercial success' (European Commission 1994). The reverse is also found, and has been called the Austrian paradox, after the country that exhibits this combination of low $\mathrm{R} \& \mathrm{D}$ expenditures but nevertheless very strong economic performance.

\section{NATIONAL SYSTEMS OF INNOVATION: INSTITUTIONS}

The different patterns in innovative performance and sectoral specialization by country have attracted quite a degree of attention in recent years (for example, Archibugi and Pianta 1994; Patel and Pavitt 1994, 1996). And they have posed new riddles to be investigated. Why are some countries more innovative than others? And in other fields? Why do some countries, time and time again, create totally new products and new industries while others rarely create either? Why do some countries make radical innovations but fail to market them successfully, while others make more incremental innovations, yet have more commercial success? Why do countries differ in their styles of innovativeness and in the industries in which they have been successful?

The differences between countries suggest that nation-specific factors shape the innovation processes. Nationally specific structures of organizations and institutions may make the difference. And unlike in traditional economics of innovation, institutions - read regulations - may not only, or not so much, be constraints, as also challenges for innovation. They may structure the possibilities as well as the incentives, and the amount and appropriate nature of the supply of resources, which all affect the effectiveness of firms in 
building up the organizational competencies needed for innovation, especially in sectors experiencing rapid technological change.

In a seminal study, David Landes (1969) argued that Germany was so successful in the second industrial revolution because of the characteristics of its education and research systems, which were lacking in Britain and elsewhere. This helped Germany to create new industries based on chemistry and physics. More recently, authors such as Freeman (1987), Nelson (1987, 1988, 1993), Porter (1990), Lundvall (1992) and Edquist (1997) have coined the concept of a 'national innovation system' (NIS) to describe such an institutional environment. Richard Nelson (1993), for example, coordinated a cross-national, multi-authored comparative study of national innovation systems. The authors in these studies have looked for answers in the institutional make-up of different societies. However, they have restricted their attention mainly to the 'institutions' (that is sectors of society) that provide the immediate relevant resources for innovation: finance, skilled personnel and public knowledge. In other words, they have focused on banking and finance, training systems, public research institutions and the science and technology policies of the state. However, this is only a rather limited initial investigation of the relevant institutional environment. What needs to be done is:

1. Look more into the black box in which innovation inputs are transferred into innovation outputs (that is, inside the limited amount of variables that NIS research has looked into): number, size and types of organizations that do the innovating (usually firms), their intra- and inter-organizational structures, their innovation strategies and their learning capacity, given that innovation involves learning processes.

2. Identify and analyse a still broader institutional framework (also outside the limited amount of variables studied in NIS research). This requires a more sociological use of the term institutions, as 'social rule systems'. Which social rule systems in a society structure or influence: a) the organizations involved in innovation; b) their mutual relations - markets, inter-firm relations like joint ventures, alliances, associations, or more generally the relation between competition versus coordination in interorganizational relations; c) their supporting institutions; d) the incentive structures in both. To what extent do these elements mutually support and reinforce each other, that is, do they have a systemic character (inhibiting the transfer of a single element to another society where these elements will find themselves in a different context)?

3. Elaborate and explicate the relation between innovating business organizations and institutions. Our aim should be to understand better the interface between institutions, organizations and innovation. How do 
institutions influence the process of innovation, among other things through the organizations involved? How is the institutional framework linked to the supporting institutions of finance, training and knowledge production, and these in turn to firm structures and strategies, including inter-firm relations? How do institutions give rise to different types of firm-organizations, to different types of products, to innovation of these, and, ultimately to the competitiveness of specific countries in various product markets? How do they structure the options and incentives in innovation strategies? On the whole, the organizational perspective has been concerned with the influence of internal characteristics of organizations on innovative activity. This literature has generally not given much attention to the way the institutional environment of organizations influenced their structures, and in turn, innovations within organizations (see Walton 1987; Lanciano et al. 1993). To be sure, there are organizational analysts who have studied the institutional environment within which organizations are embedded (among others Zucker 1987; Granovetter 1985), but they have been less concerned with how the institutional environment of organizations gives rise to particular organizational structures which are associated with specific industries, and their performance with specific links in the chain of innovation.

4. Investigate how these 'systems' of organizations and institutions persist over time and at other times change, and under which conditions they do so. How important is path dependency, that is, are present sectoral specializations of countries still the result of past choice and past contingencies?

The studies in this book will investigate these issues within the context of 'national innovation systems'. We do so by scanning quite a variety of literatures - which often exist next to each other, without knowing much about one another - to see what they have to offer to clarify the organizational and institutional dimensions of 'national innovation systems' and what they can or could add to an explanation of the national differences in innovative performance and sectoral specialization found.

\section{THE IDEA-INNOVATION CHAIN}

Most of the chapters structure their investigation of the literature around the concept of the idea-innovation chain (Hage and Hollingsworth 1997). This concept refers to the linkages between scientific research and the industrial innovation chain (Ballard et al. 1989). The idea-innovation chain consists of loosely to tightly connected - networks of (sub)organizations involved in the 
various functional domains (classes of required competences) of the innovation process: basic research, applied research, product development, manufacturing, quality control and marketing. Each of these functional domains or stages in the innovation process can be further subdivided, for example:

1. Basic research:

- monitoring of advances elsewhere in the scientific environment

- actual new basic research

- firefighting (that is, resolving problems).

2. Product development:

- development in the narrower sense of the word

- design

- prototype development

- testing (for example, field tests in biotechnology).

3. Manufacturing:

- raw materials

- intermediate products and parts

- final assembly.

4. Marketing:

- market scanning

- building up of social acceptance for products

- logistics (getting products to markets)

- sales

- after sales service.

The concept of an idea-innovation chain does not necessarily imply a uni-directional or linear relationship, nor merely a sequential interdependence between its various components. In some stages of the development of science, in some industries and in some countries, innovations may well be organized according to such a linear model of innovation. However, the development of technologies has often predated the scientific knowledge underlying the production processes. As Richard Nelson (1993: 7) reminds us, 'The advent of new technologies often leads to scientific work aimed at understanding these technologies'. Also, new instrumentation has led to new agendas in science and even the creation of new industries, as is the case with the development of gene splicing and gene sequencing instruments for example. With the emergence of science-based industries, a new mode in the production of knowledge has been observed which is characterized by the fact that technology and science are closely intertwined (Gibbons et al. 1994). In this 'mode II' of the production of knowledge, innovation is often a process of moving back and forth between invention and/or design, development and 
testing, redesign and evaluation of market potential (Kline and Rosenberg 1986). What is more, engineers have their own path dependencies and cultural resources which provide the impetus for much of their own innovative activity. New instruments and materials frequently evolve from older ones. In short, new science builds on old science as well as on new and old technology. In terms of the typology of interdependencies of Thompson (1967) and Mintzberg (1979) one could say that the idea-innovation chain is characterized not only by - and not by so much - 'sequential interdependence', as well as by reciprocal (with feedback loops) and pooled interdependence.

To express these interdependencies, one could perhaps also better speak of an innovation cycle rather than a chain, as Nooteboom does in this study (Chapter 5); in his terms this is a cycle of exploration (involving basic and applied research and product development) and exploitation (manufacturing and marketing).

Figure 1.3 contains a diagram of the idea-innovation chain. We have distinguished five levels of analysis, from the bottom up:

1. The output or performance of each functional domain. Note that some of the traditional indicators for innovativeness (money invested in research, number of patents and export trade balances for designated high-tech products) measure the performance of different phases in the ideainnovation chain. Money invested in research is an indicator of performance in the idea generation phase, patents registered indicate ideas actually generated, even if not (yet) commercialized, and trade balance scores are evidence of the successful commercialization of innovative ideas.

2. The organization of the basic units, carriers of competencies, that fulfil the various functions involved in innovation.

3. Institutions 1. The institutions as commonly envisaged in the national systems of innovation literature: the supporting institutions, or the sectoral sources of resources (capital, labour, information and knowledge) from which the firms in the idea-innovation chain have to acquire their resources.

4. Institutions 2. The national institutional frameworks, which structure the sources of sectoral resources. In most cases a specific set of institutions structures a particular sectoral source of resources, for example, finance: structured by the system of banking, financial markets, regulation of financial markets and corporate governance. These 'framing' institutions form a cluster together with the direct sectoral sources of resources.

5. The meta-institutions that influence the national institutional frameworks. The most important are: a) regulation and the legal system; b) national cultural values. 
5. Meta-Institutions $\longrightarrow$ State (laws, regulation, industrial and technology policy) and cultural values History, tradition and path dependency

4. National Institutional Frameworks

3. Sectoral Resources

\section{Capital Markets}

Corporate governance;

structure of capital

markets; company law

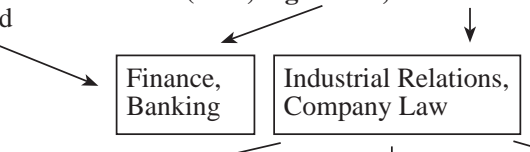

Labour Markets

How are skills and competencies organized; Labour relations

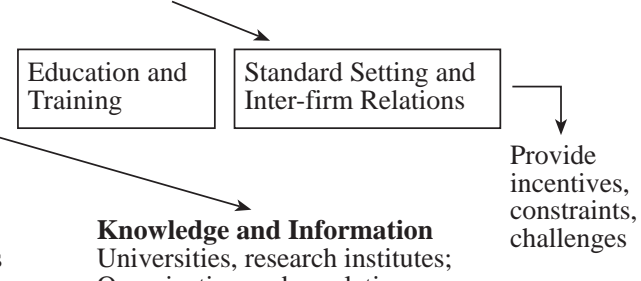

Technological Characteristics

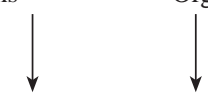

ch institutes

Organization and regulation

\section{Market Structure Characteristics}

Sector specific constraints on the organization of competencies within

2. The Idea-Innovation Chain

Flows of people, money, information the idea-innovation chain

Patterns of differentiation Locus of

Trade and coordination

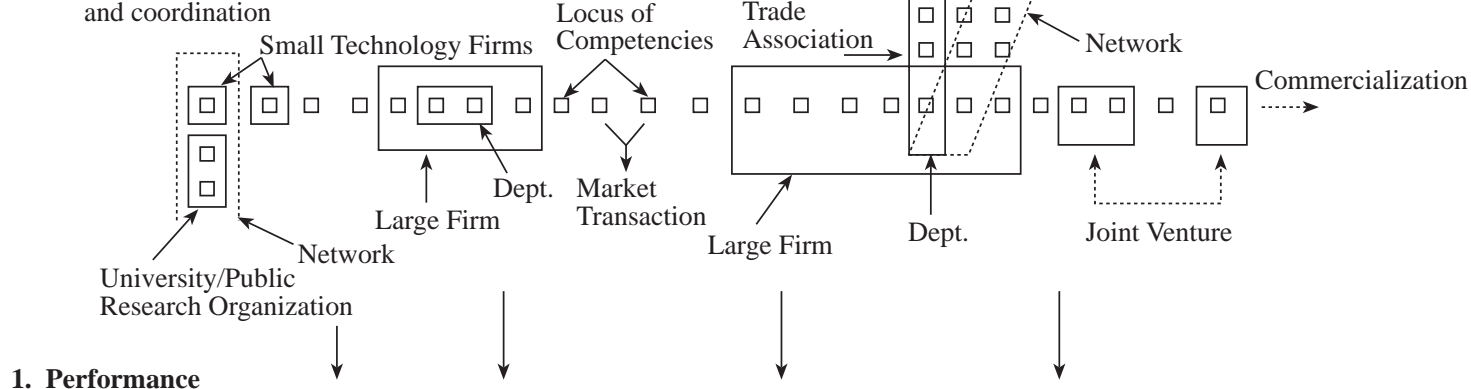
Indicators

Ideas

Patents

New Products

Growth, Trade Balance 
We believe that the idea-innovation chain concept can be used as a research tool to facilitate comparative institutional analysis on innovation. Within this scheme institutions at different levels of analysis are explanatory variables, ultimately impacting on patterns of performance across sectors within particular countries. Organizational structures may be thought of as the basic unit of analysis within idea-innovation chains, and also often have explanatory power as intervening variables (as stressed in particular by organizational sociologists). Schematic representations of the structuring of particular competencies may serve as a focusing device to understand relationships between institutional contexts, organization and performance. Structured comparisons of the organization of competencies within idea-innovation chains, for example across similar sectors in different nations or across different sectors within one country, should help reveal problems that may be explained through comparative institutional analysis. For example, many have argued that the United States has a performance advantage in commercializing basic research, especially compared to more 'organized' economies such as Germany (see for example Casper 2000). Through examining the organization of university-industry relationships within the context of the idea-innovation chain across a sector such as biotechnology, differences in the structuring of technology transfer processes may be revealed, facilitating further institutional analysis.

\section{THE DIFFERENT LITERATURES}

A key problem impeding research linking innovation processes to institutions is intellectual fragmentation across the relevant fields of study. For example, organizational sociologists and institutional economists have both examined aspects of the innovation process, but in doing so have identified dramatically different 'problems' that typically hinder successful innovation. Organizational sociologists have proposed a number of useful concepts, such as the amount of 'differentiation' within organizations, the 'coupling' of various units involved in key processes, or the degree to which organizations have an 'organic' as opposed to a hierarchical structure. Institutional economists, on the other hand, tend to examine how the distribution of incentives and information within complex settings creates incomplete contracting problems, making it difficult for either simple markets or hierarchies to be used to orchestrate the innovation process. Institutional economists have examined how a wide variety of organizational forms (such as joint ventures and networks, as well as different types of incentive and measurement systems within large organizations) can be used to align the incentives of different actors within the innovation chain. 
Similar intellectual fragmentation exists within the study of institutions. While scholars working within the fields of economic sociology and especially comparative political economy have developed sophisticated treatments of why differences in national institutional frameworks continue to exist in a rapidly globalizing economy, few scholars within these disciplines aim to employ macro-level institutional analysis to understand micro-level patterns of innovation. For this project to succeed, we must learn how to construct interfaces connecting innovation processes with institutional frameworks or structures. We need to examine carefully how firms and other organizational actors active within the innovation process engage institutional frameworks to solve problems. We wish to move beyond rather static explanations that in essence attempt to 'read off' the behaviour of organizations directly from institutional architectures. Rather, we see institutions as providing 'tool kits' that actors can use in a myriad of ways to solve organizational problems.

The design of future studies linking institutions, innovation and public policy requires an interdisciplinary approach. This requires taking stock of the literature in - and building upon the knowledge and insights from - a variety of fields of scholarship, such as the economics of innovation, institutional economics, industrial organization, organizational sociology, economic sociology, political economy, economic history, history of technology, law and sociology of law.

The 'theme group' on innovation, assembled at the Netherlands Institute for Advanced Studies in Wassenaar, comprised scholars from such a diversity of disciplinary backgrounds, but all with a common interest in innovation. They came from (institutional) economics, industrial organization, sociology (in particular economic sociology, political sociology and sociology of law), organizational theory, business administration and history of technology. For the present project they have contributed overviews of the relevant literatures that they are familiar with in the following chapters. We now present an overview of these chapters.

\section{STRUCTURE OF THE STUDY}

We have organized the study into four sections, to provide a general introduction to the field of national innovation systems and then explore different levels of analysis, as seen through the idea-innovation chain concept.

The first part of the book, including this introductory chapter, examines general exploratory frameworks used to examine national systems of innovation. Following this introduction, the second chapter focuses on our core dependent variable from the idea-innovation chain framework: 
performance. This chapter, written by Brigitte Unger, examines problems of measuring innovative performance. As we do not do an empirical investigation here we have chosen not to present comparative performance data. However, in line with the literature survey approach, Brigitte Unger presents an overview of the literature on performance indicators, and discusses the pros and cons, the advantages and problems connected with indicators for the performance of different functional domains.

The following chapter, by Marius Meeus and Leon Oerlemans, provides an overview of the extensive literature on national systems of innovation. The chapter emphasizes the diversity of research in this area, using comparisons of national innovation studies developed by economists, organizational theorists and innovation experts to examine a wide range of concepts, ranging from the innovativeness of regional economies, to technology policy, to the innovativeness of firms. Meeus and Oerlemans help make sense of the increasingly vast landscape of national systems of innovation research, providing definitions, conceptual lenses, different levels of analysis and emergent trends within this research field.

In Part II of the book we deal with the inside of the black box: the organizations and clusters or networks of organizations that transfer inputs into outputs. Here we take a more micro-level view, focusing on how a variety of organizational characteristics and forms of inter-firm coordination promote innovation, primarily from the perspective of learning. We draw in particular upon organizational theory, institutional economics and the literature within the 'national innovation systems' approach that deals with organizational learning, and emphasizes the importance of proximity to learning.

The first of these chapters, by Jerry Hage, examines contributions from organizational sociology and administrative science to the study of innovation. A core concern of organizational sociology scholars is the increased decentralization of most competencies involved in commercial activities within the advanced industrial economies. Hage discusses the implications of increased decentralization on core organizational issues, such as complexity, types of organizational form (organic, mechanistic) and inter-organizational integration. This review examines the implications of increased differentiation and specialization of activities on the structure of organizations, networks of organizations and, finally, across the idea-innovation chain.

A second chapter on organizational analysis, by Bart Nooteboom, examines patterns of innovation and organizational learning as framed by the field of institutional economics. This chapter reviews a number of literatures from the field of institutional economics that discuss innovation in the form of different types of learning. The focus is primarily on inter-firm organization and the creation of relationships that may lead to 'interactive learning' while coping with a variety of economic dilemmas emphasized by economics of 
organization scholars, in particular the transaction cost school. Nooteboom also contrasts transaction cost theory with constructivist approaches to the theory of the firm and presents an overview of typologies of learning, theories of knowledge and cognitive complexity.

We conclude this section of the book with a second chapter written by Meeus and Oerlemans, evaluating literatures focusing on networks, interactive learning and spatial theories of innovation. Scholars interested in patterns of learning from sociological and institutional economics perspectives have both emphasized the importance of interaction, particularly within interorganizational contexts. In addition to a general 'systems of innovation' school based on Lundvall's concept of 'interactive learning', this approach has increasingly emphasized the spatial implications of innovation processes. Due to its strong micro-foundation based on interactive properties, these studies tend to be more narrowly focused than the institutional approaches found within the varieties of capitalism school, focusing primarily on patterns of inter-firm organization within different institutional contexts and the role of a number of public institutions (universities, technology transfer agencies and so on). However, because of the emphasis on learning and innovation, concepts developed within the broad systems of innovation approach are of central relevance for further research on idea-innovation chains. This review first provides an overview of patterns of organizational learning and competence formation from the interactive learning perspective, then reviews the literatures on regional systems of innovation.

Part III of the book shifts the focus of analysis to institutional theory. This section contains a chapter dedicated to recent trends in comparative institutional theorizing surrounding 'varieties of capitalism' and a chapter dedicated to law and regulatory analysis.

The chapter on varieties of capitalism, written by Steven Casper, J. Rogers Hollingsworth and Richard Whitley, provides an overview of the literatures on social systems of production and sectoral economic governance, and references to some of the comparative political economy literature on institutions. This literature helpfully points to differences in the institutional organization of advanced industrial economies that are linked to differences in patterns of industrial organization and industry specialization. It also points to key variations in particular institutional sectors of the economy, namely the financial system, industrial relations system, education and vocational training system and so forth, which are linked to differences in the innovative activities of firms.

Following the general overview of the varieties of capitalism approach, our second chapter on institutions, written by Frans van Waarden, examines more carefully how constellations of institutions within particular economies influence the structure of idea-innovation chains. It does so by selecting one 
concrete set of institutions for closer scrutiny, an institution that is both idealtypical (for institutions defined as social rule systems), has the character of a 'meta-institution' (in that it defines and forms most of the other societal institutions, such as finance, training, research and standardization), and can be directly used as an instrument of intervention, namely the legal system. This includes both statutory regulation (of different degrees of abstraction and aggregation), the styles by which regulations are implemented and enforced, and case law as produced by the courts. It scans the possible influence of civil law (property, contract, corporate governance), of tort and liability law, and of social and economic regulation on innovation. The chapter draws on the literature of the sociology of law, and much of this has been concerned with concrete legal systems.

Finally the concluding chapter, contained in Part IV of the book, summarizes the contributions of the chapters on organizational and institutional analysis to innovation studies. Regrettably enough, we could not devote separate attention to the third dimension, that of time and history. We merely point here again to the importance of path dependency on innovation, to the influence of traditions (often supported by well-established institutions) in sector specialization, technology and economic governance institutions.

\section{REFERENCES}

Amable, B. and B. Hancke (2001), 'Innovation and industrial renewal in France in comparative perspective', Industry and Innovation, 8(2), 113-34.

Archibugi, D. and M. Pianta (1994), 'Aggregate convergence and sectoral specialization in innovation', Journal of Evolutionary Economics, 4, 17-33.

Ballard, S., T. James Jr., T. Adams, M. Devine, L. Malysa and M. Meo (1989), Innovation through Technical and Scientific Information: Government and industry cooperation, New York: Quorum.

Casper, S. (2000), 'Institutional adaptiveness, technology policy, and the diffusion of new Business Models: the case of German biotechnology', Organization Studies, 21, 887-914.

Dutch Ministry of Economic Affairs (1995), Toets op het Concurrentievermogen (Benchmarking the Netherlands), The Hague: Ministry of Economic Affairs.

Dutch Ministry of Economic Affairs (1997), Toets op het Concurrentievermogen (Benchmarking the Netherlands), The Hague: Ministry of Economic Affairs.

Edquist, C. (ed.) (1997), Systems of Innovation: Technologies, institutions and organizations, London: Pinter Publishers.

European Commission (1994), White Paper on Growth, Competitiveness, Employment: The challenges and ways forward into the $21^{\text {st }}$ century, $\operatorname{COM}(93) 700$, Brussels, EC.

European Commission (1995), Green Paper on Innovation, Brussels and Luxembourg: ECSC-EC-EAEC.

Freeman, C. (1987), Technology Policy and Economic Performance: Lessons from Japan, London: Pinter Publishers. 
Gibbons, M., C. Limoges, H. Nowotny, S. Schwartzman, P. Scott and M. Trow (1994), The New Production of Knowledge: The dynamics of science and research in contemporary societies, London: Sage.

Granovetter, M. (1985), 'Economic action and social structures: the problem of embeddedness', American Journal of Sociology, 91 (November), 481-510.

Hage, J. and J.R. Hollingsworth (1997), Idea-innovation Networks: Integrating Institutional and Organisational Levels of Analysis. Paper presented to an EMOT workshop on 'Economic Performance Outcomes in Europe: The role of national institutions and forms of economic organization', held at the Wissenschaftszentrum Berlin WZB, Berlin, 30 January-1 February.

Hall, P. and D. Soskice (2001), 'Introduction', in P. Hall and D. Soskice (eds), Varieties of Capitalism, Oxford: Oxford University Press, pp. 1-68.

Kline, S. and N. Rosenberg (1986), 'An overview of innovation', in R. Landau and N. Rosenberg (eds), The Positive Sum Strategy, Washington DC: National Academy Press.

Lanciano, C., M. Maurice, H. Nohara and J.J. Silvestre (1993), L’Analyse Sociétale de l'Innovation: Genèse et développement. Unpublished paper, Laboratoire d'Economie et de Sociologie du Travail, Aix-en-Provence (France), 1993/2.

Landes, D.S. (1969), The Unbound Prometheus: Technological change and industrial development in Western Europe from 1750 to the present, Cambridge: Cambridge University Press.

Lundvall, B.-A. (1992), National Systems of Innovation: Towards a theory of innovation and interactive learning, London: Pinter Publishers.

Mintzberg, H. (1979), The Structuring of Organizations, Englewood Cliffs, NJ: Prentice-Hall.

Nelson, R.R. (1987), Understanding Technical Change as an Evolutionary Process, Amsterdam: North-Holland.

Nelson, R.R. (1988), 'Institutions supporting technical change in the United States', in G. Dosi, C. Freeman, R. Nelson, G. Silverberg and L. Soete (eds), Technical Change and Economic Theory, London: Pinter Publishers, pp. 312-29.

Nelson, R.R. (ed.) (1993), National Innovation Systems: A comparative analysis, New York: Oxford University Press.

Patel, P. and K. Pavitt (1994), 'National Innovation Systems: why they are important and how they might be measured and compared', Economics of Innovation and New Technology, 3, 77-95.

Patel, P. and K. Pavitt (1996), 'Uneven technological development', in X. Vence-Deza and J.S. Metcalfe (eds), Wealth from Diversity, Dordrecht: Kluwer, pp. 39-75.

Porter, M. (1990), The Comparative Advantage of Nations, New York: Free Press.

Thompson, J.D. (1967), Organizations in Action, New York: McGraw-Hill.

Walton, R. (1987), Innovating to Compete: Lessons for diffusing and managing change in the workplace, San Francisco: Jossey-Bass.

Zucker, L. (1987), 'Institutional theories of organization', American Social Review, 95, 445-6. 